\title{
Analisis kesalahan siswa dalam menyelesaikan masalah matematis pada materi himpunan
}

\author{
Deden Wahyu Hidayat', Heni Pujiastuti² \\ 1. Magister Pendidikan Matematika, Pascasarjana, Universitas Sultan Ageng Tirtayasa, \\ Jl. Raya Jakarta Km. 4 Pakupatan, Serang, Indonesia. \\ 2. Jurusan Pendidikan Matematika, Fakultas Keguruan dan Ilmu Pendidikan, \\ Universitas Sultan Ageng Tirtayasa, Jl. Raya Jakarta Km. 4 Pakupatan, Serang, \\ Indonesia. \\ henipujiastuti@untirta.ac.id
}

DOI :10.15575/ja.v5i1.4120

Received: 04 Januari 2019 ; Accepted: 15 Mei 2019 ; Published: 29 Juni 2019

\begin{abstract}
ABSTRAK
Penelitian ini merupakan penelitian deskriptif dengan pendekatan kualitatif yang bertujuan untuk mendeskripsikan jenis-jenis kesalahan dan persentase kesalahan siswa dalam menyelesaikan masalah matematis khususnya pada materi Himpunan. Subjek penelitian ini yaitu siswa kelas VII SMP Negeri Satu Atap 4 Maja Kabupaten Lebak. Instrumen yang digunakan dalam penelitian ini diantaranya yaitu tes kemampuan pemecahan masalah matematis dan pedoman wawancara. Langkah-langkah penyelesaian masalah yang dianalisis terdiri atas empat tahap, yaitu: memahami soal, menyusun rencana, melaksanakan rencana, dan memeriksa kembali solusi yang diperoleh. Hasil penelitian yang dilakukan menunjukkan bahwa kesalahan memahami soal sebesar 4,4\% kesalahan menyusun rencana sebesar 16,5\%; kesalahan melaksanakan rencana sebesar 17,0\%; dan kesalahan memeriksa kembali solusi yang diperoleh sebesar 14,8\%. Kesalahan melaksanakan rencana disebabkan siswa kurang hati-hati dalam melakukan perhitungan matematika dan siswa juga kurang hati-hati dalam menentukan kesimpulan terhadap permasalahan yang diberikan.
\end{abstract}

Kata kunci: Analisis, Kesalahan, Himpunan

\begin{abstract}
This research is a descriptive study with a qualitative approach that aims to describe the types of errors and the percentage of students' errors in solving mathematical problems, especially in the set material. The subjects of this study were 7th grade students SMP Negeri Satu Atap 4 Maja Kabupaten Lebak. The instruments used in this study include the test of mathematical problem solving abilities and interview guidelines. The problem solving steps analyzed consist of four stages, namely; understanding the problem, arranging the plan, implementing the plan, and re-examining the solution obtained. The results of the research conducted indicate that the problem of understanding errors is 4.4\%; misplaced plans of 16.5\%; error implementing the plan of $17.0 \%$; and errors checking back the solution obtained was $14.8 \%$. Errors in carrying out the plan are caused by students not being careful in doing mathematical calculations and students are also not careful in determining conclusions on the problems given
\end{abstract}

Keywords: Analysis, Mistake, Set 


\section{PENDAHULUAN}

Matematika merupakan cabang ilmu yang sering digunakan dalam berbagai ilmu pendidikan dan juga merupakan ilmu universal yang mendasari perkembangan teknologi modern. Tidak dapat dipungkiri bahwa peran matematika sebagai salah satu cabang ilmu pengetahuan yang banyak mendasari perkembangan ilmu pengetahuan yang lain. Oleh karena itu, matematika perlu disampaikan sejak dini, dengan tujuan agar siswa mampu berfikir kritis, logis, sistematis, cermat, efektif, dan efisien dalam memecahkan masalah.

Dilihat dari pentingnya matematika untuk dipelajari, maka siswa harus bersungguhsungguh belajar matematika di sekolah (Rohimah \& Maryono, 2017). Cornelius mengemukakan lima alasan perlunya belajar matematika karena matematika merupakan: (1) sarana berfikir yang jelas dan logis; (2) sarana untuk memecahkan masalah kehidupan sehari-hari; (3) sarana mengenal pola-pola hubungan dengan generalisasi pengalaman; (4) sarana untuk mengembangkan kreatifitas; dan (5) sarana untuk meningkatkan kesadaran terhadap perkembangan budaya (Abdurrahman, 2012).

Dalam proses pembelajaran, gurulah yang berperan untuk menciptakan kondisi belajar mengajar yang dapat mengantarkan siswa memperoleh kompetensi yang sudah ditetapkan. Belajar dan mengajar matematika memang tidak mudah, namun apabila dilakukan dengan baik serta mengetahui dan memahami tentang arti, konsep, dan makna pelajaran matematika maka akan dirasakan mudah. Agar konsep matematika yang dipelajari menjadi lebih mudah dipahami dan dapat diklasifikasikan dalam kehidupan sehari-hari, maka dalam pembelajaran matematika penekanan dalam keterkaitan antara konsep-konsep matematika dengan pengalaman anak sehari-hari sangat penting dilakukan.

Salah satu tujuan dalam pembelajaran matematika adalah membantu siswa dalam menyelesaikan pemecahan masalah, baik itu masalah yang berhubungan dengan pemahaman konsep matematika itu sendiri maupun yang berhubungan dengan masalah dalam kehidupan sehari-hari (Susilawati, Syaf, \& Susilawati, 2017).

Himpunan merupakan salah satu materi pokok dalam matematika SMP kelas VII semester I. Belajar materi himpunan adalah belajar konsep, tidak terdapat banyak rumus dalam materi ini, hanya saja dalam materi ini digunakan berbagai macam simbol, notasi, dan diagram. Belajar materi himpunan membutuhkan pemahaman konsep yang baik. Pemahaman tentang matematika lebih luas akan mempermudah perserta didik dalam mempelajari himpunan terutama pada bentuk pemecahan masalah. Karakteristik dasar materi himpunan dalam pemecahan masalah diantaranya berupa soal-soal cerita yang membutuhkan pemahaman konsep untuk dapat mengidentifikasi dan menyelesaikan masalah yang berkaitan dengan himpunan.

Kenyataan yang ada bahwa 75\% siswa SMPN Satap 4 Maja Kabupaten Lebak yang mengeluh dikarenakan sering mengalami kesulitan dalam memahami soal-soal matematika sehingga siswa seringkali melakukan kesalahan dalam menyelesaikan soal-soal yang diberikan, belum lagi banyak para siswa yang tidak cocok dengan metode pengajaran matematika yang diberikan oleh gurunya. Menurut (Diona Amelia, Susanto, 2015) kesalahan yang banyak dilakukan siswa dalam soal yang memuat konsep irisan dan gabungan, serta siswa juga kurang bisa dalam memahami bahasa yang diajukan dalam soal yang disajikan. Oleh karenanya, tidak berlebihan jika sampai saat ini mata pelajaran matematika dipandang sebagai mata pelajaran yang paling sulit. Bagi sebagian besar siswa SMP, matematika seringkali menjadi suatu mata pelajaran yang menakutkan sehingga akan semakin menurunkan minat dan semangat siswa tersebut dalam belajar matematika baik itu di rumah maupun di sekolah. Kenyataan ini didukung pula dengan kemerosotan mutu lulusan yang ditandai oleh rendahnya prestasi belajar matematika dibanding dengan mata pelajaran yang lain.

Berdasarkan observasi lapangan yang dilakukan peneliti terhadap siswa di SMP 
Negeri Satap 4 Maja Kabupaten Lebak, masih banyak siswa yang merasa kesulitan pada materi himpunan. Kesulitan tersebut dapat memunculkan terjadinya banyak kesalahan ketika mengerjakan soal cerita himpunan. Masih banyak siswa yang tidak menyelesaikan soal dengan benar dikarenakan tidak memahami langkah pengerjaannya. Hal ini mungkin disebabkan karena operasi pada himpunan berbeda dengan operasi pada bilangan real maupun bilangan bulat yang telah dikenal siswa sebelumnya.

Kesalahan tersebut tidak bisa diketahui letak dan penyebabnya, karena dalam jawaban siswa langsung menuliskan hasil akhirnya. Kesalahan-kesalahan yang dilakukan siswa dalam menyelesaikan soal matematika perlu diidentifikasi atau dianalisis, dengan tujuan untuk mengetahui letak kesalahan dan penyebab kesalahan sehingga hasil analisis kesalahan dapat dijadikan dasar dalam memberikan bantuan yang sesuai.

Penelitian tentang kesalahan siswa dalam menyelesaikan soal dapat dilakukan untuk menganalisis kesulitan siswa dalam belajar matematika agar dapat diberikan bimbingan yang tepat sehingga kemampuan siswa bertambah baik. Oleh karena itu, dilakukan penelitian tentang analisis tipe-tipe kesalahan dalam menyelesaikan soal-soal cerita materi himpunan pada siswa kelas VII-B di SMP Negeri Satu Atap 4 Maja Kabupaten Lebak.

Tujuan penelitian ini adalah untuk menganalisis tipe-tipe kesalahan apa saja yang dilakukan siswa dalam menyelesaikan soal-soal himpunan. Diharapkan hasil penelitian ini dapat dijadikan dasar oleh guru dalam memberikan bantuan secara tepat kepada siswa yang masih melakukan kesalahan dalam menyelesaikan soal cerita dalam materi himpunan dan dapat dijadikan sebuah bahan refleksi untuk menentukan halhal apa saja yang harus ditekankan dalam mengajarkan materi himpunan.

\section{METODE PENELITIAN}

Jenis penelitian yang digunakan dalam penelitian ini adalah penelitian deskriptif dengan pendekatan kualitatif. Penelitian deskriptif tidak memerlukan administrasi atau pengontrolan terhadap suatu perlakuan. Adapun subyek penelitian diambil dari siswa kelas VII-B SMP Negeri Satu Atap 4 Maja Kabupaten Lebak Banten Tahun ajaran 2018/2019 sebanyak dua puluh tujuh siswa. Lokasi Penelitian adalah SMP Negeri Satu Atap 4 Maja yang terletak di Kecamatan Maja Kabupaten Lebak Banten.

Instrumen penelitian yang digunakan yaitu:

1. Lembar Tes

Tes kemampuan pemecahan masalah matematis dalam penelitian ini berbentuk soal cerita yang berkaitan dengan himpunan.

2. Pedoman Wawancara

Wawancara digunakan untuk mengumpulkan data berupa kata-kata yang merupakan ungkapan secara lisan tentang kesalahan-kesalahan yang dilakukan siswa dalam memahami soal cerita matematika.

Sumarmo (2002) menyatakan bahwa pembelajaran matematika perlu diarahkan untuk pemahaman konsep dan prinsip matematika yang kemudian diperlukan untuk menyelesaikan masalah matematika, masalah dalam disiplin ilmu lain, dan masalah dalam kehidupan sehari-hari (Mulyati, 2016).

Kesalahan siswa dalam menyelesaikan soal cerita pada penelitian ini didefinisikan sebagai penyimpangan yang dilakukan siswa dalam menyelesaikan soal cerita yang diberikan terhadap langkah-langkah penyelesaian berdasarkan Polya. Jenis kesalahan yang dimaksud yaitu: (1) kesalahan memahami soal; (2) kesalahan menyusun rencana; (3) kesalahan melaksanakan rencana; dan (4) kesalahan dalam memeriksa kembali solusi yang diperoleh (Mulyati, 2016). Penjelasan lebih lanjut mengenai indikator jenis kesalahan siswa dalam menyelesaikan soal cerita pada penelitian ini disajikan pada Tabel 1 berikut. 
Tabel 1. Indikator Kesalahan Siswa dalam Menyelesaikan Soal Himpunan

\begin{tabular}{|c|c|c|}
\hline \multicolumn{2}{|c|}{ Jenis Kesalahan } & Indikator \\
\hline $\begin{array}{l}\text { Kesalahan } \\
\text { Memahami Soal }\end{array}$ & $\begin{array}{l}\text { Kesalahan menentukan } \\
\text { apa yang diketahui }\end{array}$ & $\begin{array}{l}\text { a. Siswa menuliskan dengan benar apa yang diketahui } \\
\text { dalam soal. } \\
\text { b. Siswa salah dalam menuliskan apa yang diketahui } \\
\text { dalam soal. } \\
\text { c. Siswa tidak menuliskan apa yang diketahui dalam } \\
\text { soal. }\end{array}$ \\
\hline & $\begin{array}{l}\text { Kesalahan menentukan } \\
\text { apa yang ditanya }\end{array}$ & $\begin{array}{l}\text { a. Siswa menuliskan dengan benar apa yang ditanyakan } \\
\text { dalam soal. } \\
\text { b. Siswa salah dalam menuliskan apa yang ditanyakan } \\
\text { dalam soal. } \\
\text { c. Siswa tidak menuliskan apa yang ditanyakan dalam } \\
\text { soal. }\end{array}$ \\
\hline $\begin{array}{l}\text { Kesalahan } \\
\text { Menyusun Rencana }\end{array}$ & $\begin{array}{l}\text { Kesalahan dalam } \\
\text { menuliskan metode } \\
\text { penyelesaian }\end{array}$ & $\begin{array}{l}\text { a. Siswa menuliskan dengan benar metode } \\
\text { penyelesaian sesuai perintah soal. } \\
\text { b. Siswa menuliskan metode penyelesaian tetapi tidak } \\
\text { sesuai dengan perintah soal. } \\
\text { c. Siswa tidak menuliskan metode penyelesaian soal. }\end{array}$ \\
\hline
\end{tabular}

Kesalahan menentukan langkah-langkah dalam menyelesaikan soal a. Siswa menuliskan dengan benar langkah-langkah yang akan digunakan dalam menyelesaikan soal sesuai dengan metode yang diambil/ditentukan.

b. Siswa menuliskan langkah-langkah yang akan digunakan dalam menyelesaikan soal tetapi tidak sesuai dengan metode yang diambil/ditentukan.

c. Siswa tidak menuliskan langkah-langkah yang akan digunakan dalam menyelesaikan soal

\begin{tabular}{ll}
\hline Kesalahan & Kesalahan perhitungan \\
Melaksanakan & dalam menyelesaikan \\
Rencana & model matematika yang \\
& telah dibuat.
\end{tabular}

a. Siswa melakukan perhitungan dengan benar untuk menyelesaikan model matematika yang telah dibuat.

b. Siswa salah dalam melakukan perhitungan terhadap penyelesaian model matematika yang telah dibuat.

c. Siswa tidak melakukan perhitungan untuk menyelesaikan model matematika yang telah dibuat.
a. Siswa menuliskan dengan benar kesimpulan sesuai dengan permasalahan yang diberikan.
b. Siswa menuliskan kesimpulan tetapi tidak sesuai dengan permasalahan yang diberikan.
c. Siswa tidak menuliskan kesimpulan.

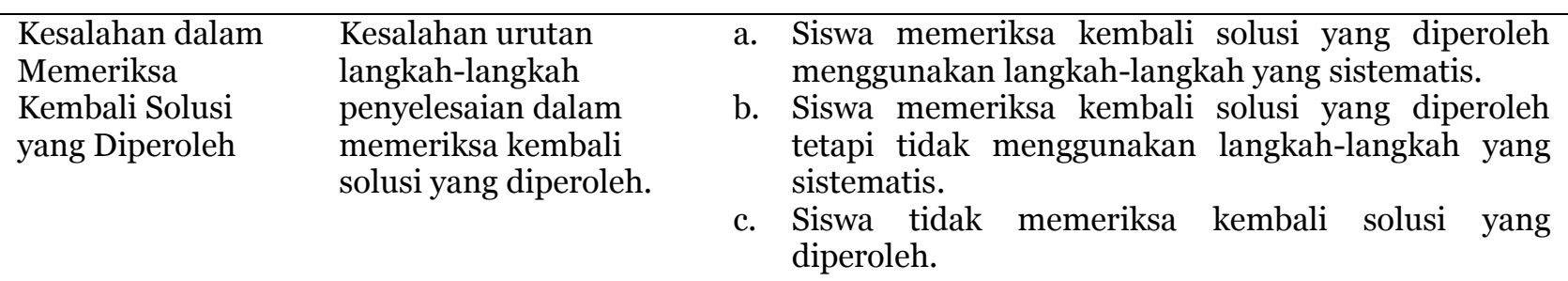




\begin{tabular}{|c|c|}
\hline Jenis Kesalahan & Indikator \\
\hline $\begin{array}{l}\text { Kesalahan perhitungan } \\
\text { matematika dalam } \\
\text { memeriksa kembali } \\
\text { solusi yang diperoleh. }\end{array}$ & $\begin{array}{l}\text { a. Siswa melakukan perhitungan dengan benar ketika } \\
\text { memeriksa kembali solusi yang diperoleh. } \\
\text { b. Siswa salah dalam melakukan perhitungan ketika } \\
\text { memeriksa kembali solusi yang diperoleh. } \\
\text { c. Siswa tidak melakukan perhitungan ketika } \\
\text { memeriksa kembali solusi yang diperoleh }\end{array}$ \\
\hline $\begin{array}{l}\text { Kesalahan memperoleh } \\
\text { jawaban akhir. }\end{array}$ & $\begin{array}{l}\text { a. Siswa memperoleh jawaban akhir sesuai dengan data } \\
\text { awal yang diberikan. } \\
\text { b. Siswa memperoleh jawaban akhir tetapi tidak sesuai } \\
\text { dengan data awal yang diberikan. } \\
\text { c. Siswa tidak memperoleh jawaban akhir. }\end{array}$ \\
\hline
\end{tabular}

\section{Analisis Data}

Data yang diperoleh pada penelitian ini berupa lembar jawaban siswa dan hasil wawancara. Data berupa lembar jawaban siswa digunakan untuk menentukan siswa yang akan diwawancarai. Kelas nilai siswa dikategorikan ke dalam kelas rendah, sedang, dan tinggi. Siswa dikelompokkan kedalam kelas nilai rendah apabila nilai siswa kurang dari kuartil bawah nilai siswa. Siswa yang nilainya lebih dari atau sama dengan kuartil bawah dan kurang dari kuartil atas dikelompokkan ke dalam kelas nilai sedang. Sedangkan siswa yang nilainya lebih dari atau sama dengan kuartil atas dikelompokkan kedalam kelas nilai tinggi (Ali, 1993).

\section{HASIL DAN PEMBAHASAN}

Dari hasil pekerjaan siswa terhadap soal tes yang diberikan, selanjutnya siswa dikelompokkan berdasarkan nilai yang diperoleh untuk menentukan tingkat kemampuan kognitifnya yaitu tingkat kemampuan kognitif tinggi, sedang dan rendah. Bloom (1976: 201-207) membagi hasil belajar menjadi kawasan yaitu kognitif, afektif dan psikomotor. Kawasan kognitif berkenaan dengan ingatan atau pengetahuan dan kemampuan intelektual serta keterampilanketerampilan. Kawasan afektif menggambarkan sikap-sikap, minat dan nilai serta pengembangan pengertian atau pengetahuan dan penyesuaian diri yang memadai. Kawasan psikomotor adalah kemampuan-kemampuan menggiatkan dan mengkoordinasikan gerak. (Lestari, 2017)

Berdasarkan jawaban siswa terhadap soal cerita yang telah dikerjakan. Selanjutnya dilakukan analisis untuk mengetahui jenisjenis kesalahan dalam mengerjakan soal-soal cerita tersebut dan persentase dari masingmasing jenis kesalahan yang dilakukan siswa. Menurut hasil analisis tersebut, diketahui bahwa terdapat empat jenis kesalahan yang dilakukan siswa yaitu: 1) kesalahan memahami soal; 2) kesalahan menyusun rencana; 3) kesalahan melaksanakan rencana; dan 4) kesalahan memeriksa kembali solusi yang diperoleh.

Berikut ini adalah data temuan keempat jenis kesalahan yang dilakukan siswa dalam menyelesaikan soal cerita mengenai Himpunan. Berdasarkan instrumen yang diberikan peneliti, jenis-jenis kesalahan siswa dalam menyelesaikan soal cerita tersebut disajikan pada Tabel 2 berikut. 
Tabel 2. Jenis-Jenis Kesalahan yang Dilakukan Siswa dalam Menyelesaikan Soal Himpunan

\begin{tabular}{clllll}
\hline $\begin{array}{c}\text { Nomor } \\
\text { Siswa }\end{array}$ & \multicolumn{1}{c}{ Soal 1 } & \multicolumn{1}{c}{ Soal 2 } & \multicolumn{1}{c}{ Soal 3 } & \multicolumn{1}{c}{ Soal 4 } & Soal 5 \\
\hline 1 & B,C,D & B,D & C & B,D & A,B,C,D \\
\hline 2 & B,C,D & B,D & B,C,D & B,C,D & A,B,C,D \\
\hline 3 & B,C,D & B,C,D & C,D & B,C,D & A,B,C,D \\
\hline 4 & B,C, & A,B,C,D & B,C,D & C,D & B,C \\
\hline 5 & B,C,D & B,D & B,D & B,C,D & C,D \\
\hline 6 & B,C,D & D & B,C,D & B,C,D & A,B,C,D \\
\hline 7 & E & D & B,C & A,B,C,D & B,C,D \\
\hline 8 & B,C,D & E & F & B,C & B,C \\
\hline 9 & B,C & B,C,D & B,C,D & B,C,D & A,B,D \\
\hline 10 & B,C,D & B,C,D & A, B,C,D & B,C,D & A,B,C,D \\
\hline 11 & B,C,D & A,B,C,D & B,C,D & B,C,D & A,B \\
\hline 12 & B,C,D & A,B,C,D & B,C,D & C,D & A,B,C \\
\hline 13 & B,C,D & B,C,D & E & A,B,C,D & A,B,C,D \\
\hline 14 & B,C, & A,B,D & B & B,C,D & C,D \\
\hline 15 & B,C,D & B,C,D & B,D & B,C,D & A,B,C,D \\
\hline 16 & B,C,D & B,C,D & B,C,D & A,B,C,D & A,B,D \\
\hline 17 & B & B,D & B,C,D & B,C,D & A,B,C, \\
\hline 18 & B,C,D & E & A, B,C,D & B,C & C,D \\
\hline 19 & B,C & B,C,D & B,C,D & B,C,D & A,B,C, \\
\hline 20 & B,C,D & B,D & B,C & B,C & C,D \\
\hline 21 & B & B,C,D & B,C,D & B,C,D & A,B,C, \\
\hline 22 & B,C,D & A,B,C,D & B,C,D & B,D & A,B,C,D \\
\hline 23 & B,C,D & B,D & B,D & B,C,D & F \\
\hline 24 & B,C,D & B,C,D & E & B,C,D & A,B,C, \\
\hline 25 & C,D & B,C,D & B,C & C,D & A,B,C \\
\hline 26 & A,B,C,D & B,C,D & B,C,D & B,C,D & E \\
\hline 27 & B,C,D & B,D & A,B,C,D & B,C,D & A,B,C, \\
\hline
\end{tabular}

Keterangan:

A : Kesalahan Memahami Soal

B : Kesalahan Menyusun Rencana

C : Kesalahan Melaksanakan Rencana

D : Kesalahan Memeriksa Kembali Solusi yang

Diperoleh
E : Tidak Ditemui Kesalahan F : Soal Tidak Dijawab

Adapun persentase dari masing-masing jenis kesalahan yang dilakukan siswa disajikan pada Tabel 3 berikut.

Tabel 3. Persentase dari Masing-Masing Jenis Kesalahan yang Dilakukan Siswa dalam Menyelesaikan Soal Himpunan

\begin{tabular}{lc}
\hline \multicolumn{1}{c}{ Jenis Kesalahan } & Persentase (\%) \\
\hline Memahami Soal & 4,4 \\
\hline Menyusun Rencana & 16,5 \\
\hline Melaksanakan Rencana & $\mathbf{1 7 , 0}$ \\
\hline Memeriksa Kembali Solusi yang Diperoleh & $\mathbf{1 4 , 8}$ \\
\hline
\end{tabular}


Dari tabel 3 dapat diketahui bahwa kesalahan yang paling banyak dilakukan siswa yaitu kesalahan dalam melaksanakan rencana dengan persentase sebesar 17,0\%. Berdasarkan hasil wawancara diketahui penyebab siswa melakukan jenis kesalahan ini adalah siswa tidak melaksanakan rencana sesuai dengan rencana yang telah mereka susun sebelumnya, siswa kurang hati-hati dalam melakukan perhitungan matematika dan siswa juga kurang hati-hati dalam menentukan kesimpulan terhadap permasalahan yang diberikan. Hal ini sesuai dengan hasil pekerjaan siswa yaitu siswa tidak menyelesaikan model matematika yang telah dibuatnya sesuai dengan langkah-langkah penyelesaian yang telah disusunnya, siswa lupa atau salah menuliskan operasi dalam perhitungan, salah dalam menghitung, dan salah dalam menuliskan satuan serta tidak menuliskan kesimpulan sesuai dengan permasalahan yang diberikan.

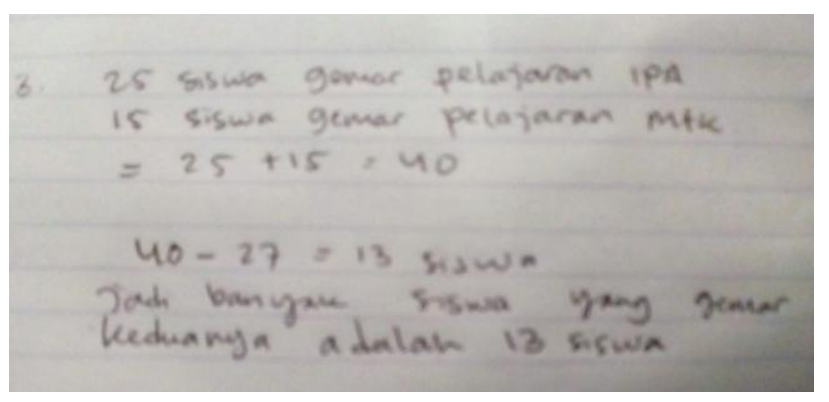

\section{Gambar 1. Hasil Jawaban Siswa}

Kesalahan menyusun rencana memiliki persentase sebesar 16,5\%. Berdasarkan hasil wawancara diketahui penyebab siswa melakukan kesalahan jenis ini adalah karena siswa tidak terbiasa dalam menuliskan rencana yang akan digunakannya dalam menyelesaikan soal, seperti: tidak menuliskan pemisalan variabel yang akan digunakan dalam membuat model matematika, tidak menuliskan metode dan langkah-langkah yang akan digunakan dalam menyelesaikan model matematika yang telah dibuatnya. Hal ini terlihat ketika siswa tidak menuliskan pemisalan variabel dari soal cerita yang diberikan, siswa tidak membuat model matematika yang sesuai dengan kalimat cerita yang ada pada soal serta tidak menuliskan metode dan langkah-langkah yang akan mereka gunakan dalam menyelesaikan model matematika yang telah dibuatnya.

Kesalahan memeriksa kembali solusi yang diperoleh memiliki persentase sebesar 14,8\%. Berdasarkan hasil wawancara diketahui penyebab siswa melakukan kesalahan jenis ini adalah karena siswa tidak terbiasa untuk memeriksa kembali solusi yang diperolehnya sehingga dalam memeriksa kembali solusi yang diperolehnya, siswa tidak menggunakan langkah-langkah yang runtut (sistematis). Hal ini terlihat dari hasil pekerjaan siswa ketika siswa menuliskan pembuktian tanpa melalui langkah-langkah yang seharusnya diselesaikan terlebih dahulu. Selanjutnya, kesalahan yang paling sedikit dilakukan siswa dalam penelitian ini adalah kesalahan dalam memahami soal yang memiliki persentase sebesar 4,4\%. Berdasarkan hasil wawancara diketahui penyebab siswa melakukan kesalahan jenis ini adalah karena siswa kurang cermat dan teliti dalam membaca soal. Hal ini terlihat dari hasil pekerjaan siswa ketika menuliskan apa yang diketahui dan ditanya dari soal yang diberikan, yaitu terdapat kata penting yang sering tidak dituliskan siswa.

Beberapa hasil penelitian yang relevan terhadap penelitian yang dilakukan oleh penulis antara lain: (1) Penelitian oleh Diona Amelia, Susanto, Arif Fatahillah yang berjudul "Analisis Hasil Belajar Matematika Siswa Pada Pokok Bahasan Himpunan Berdasarkan Ranah Kognitif Taksonomi Bloom” memaparkan hasil bahwa Kesalahan yang banyak dilakukan siswa dalam soal yang memuat konsep irisan dan gabungan, serta siswa juga kurang bisa dalam memahami bahasa yang diajukan dalam soal yang disajikan. (2) Penelitian yang dilakukan oleh E. Susilawati, A. H. Syaf, dan W. Susilawati yang berjudul "Pendekatan Eksplorasi Berbasis Intuisi Pada Kemampuan Pemecahan Masalah Matematis" memaparkan hasil bahwa peningkatan kemampuan pemecahan masalah matematis siswa yang memperoleh pembelajaran pendekatan eksplorasi berbasis 
intuisi mengalami peningkatan dengan kategori sedang. Peningkatam kemampuan pemecahan masalah matematis siswa yang memperoleh pembelajaran konvensional mengalami peningkatan dengan kategori rendah. Pendekatan eskplorasi berbasis intuisi dapat diaplikasikan pada sub pokok bahasan lain, sebagai salah satu alternatif pendekatan pembelajaran dengan aransemen agar siswa mampu beradaptasi dengan konsep yang merupakan kunci awal keberlangsungan proses pembelajaran efektif dan efisien. (3) Penelitian yang dilakukan oleh Aprilia Nugrahani yang berjudul "Analisis Kesalahan dalam Menyelesaikan Soal Cerita pada Materi Himpunan Berdasarkan Tahapan Newman pada Siswa Kelas VII A SMP Kristen Satya Wacana Salatiga" memaparkan hasil bahwa Kesalahan yag didapatkan berdasarkan tahapan Newman (Clemen,1980) pada 3 subjek kelas VIIA SMP Kristen Satya Wacana tahun ajaran 2015/2016 antara lain kesalahan dalam mentransformasi (transformation error), kesalahan proses (processing error), dan kesalahan menuliskan jawaban akhir (encoding error). Kesalahan dalam mentransformasi (transformation error) kesalahan yang terjadi karena siswa belum dapat mengubah soal ke model matematika dengan benar serta salah dalam menggunakan tanda operasi hitung, kesalahan ini terjadi karena subjek belum memahami cara mengubah ke model matematika dan belum memahami cara menyelesikan soal. Kesalahan proses (processing error) kesalahan yang terjadi karena siswa tidak terampil dalam melakukan perhitungan yang dikarenakan tidak dapat mengubah secara benar karena proses transformasi. Kesalahan menuliskan jawaban akhir (encoding error) kesalahan yang terjadi karena siswa balum bisa menuliskan jawaban akhir dengan benar (Nugrahani, 2017). (4) Penelitian yang dilakukan oleh Nurul Farida yang berjudul "Analisis Kesalahan Siswa SMP KELAS VIII dalam Menyelesaikan Masalah Soal Cerita Matematika" memaparkan hasil bahwa: (a) Siswa salah mengubah informasi yang diberikan ke dalam ungkapan matematika karena siswa tidak memperhatikan maksud soal; (b) Kesalahan tidak dapat menentukan rumus yang harus digunakan untuk menyelesaikan masalah karena lupa rumus apa yang akan digunakan dalam menyelesaikan masalah. Siswa cenderung hanya menghafal rumus yang diberikan oleh guru sehingga siswa cepat lupa dengan rumus yang sudah diberikan; (c) Kesalahan dalam aspek konsep karena telah terjadi miskonsepsi pada diri siswa; (d) Kesalahan dilakukan oleh subyek 2 dalam memahami konsep bunga perbulan jika diketahui pertahun. Subyek 2 memahami bahwa apabila persentase bunga diketahui pertahun maka yang dikerjakan adalah mengurangkan persentase bunga dengan 12. Penyebabnya karena kurang pahamnya dalam menghitung bunga perbulan jika diketahui pertahun dan juga di dalam pembelajaran kurang diberikan soal-soal yang bervariasi sehingga ketika siswa diberikan soal yang berbeda siswa tidak dapat menjawab dengan benar; (e) Kesalahan dalam menafsirkan solusi karena tidak memperhatikan apa yang ditanyakan dalam soal; (f) Hampir sebagian siswa tidak menuliskan kesimpulan karena siswa cenderung ingin menyingkat jawaban dan tidak terbiasa dalam menuliskan kesimpulan; (g) Kesalahan dalam perhitungan karena terburu-buru dan kurang teliti dalam melakukan perhitungan (Nurul Farida, 2015).

\section{KESIMPULAN}

Dari hasil penelitian analisis kesalahan dalam menyelesaikan soal Himpunan siswa kelas VIIB SMP Negeri Satu Atap 4 Maja didapatkan kesimpulan: 1) Jenis-jenis kesalahan yang dilakukan siswa antara lain; a) Kesalahan memahami soal, dapat dilihat dari hasil pekerjaan siswa ketika menuliskan apa yang diketahui dan ditanya dari soal yang diberikan, yaitu terdapat kata penting yang sering tidak dituliskan siswa; b) Kesalahan menyusun rencana, dapat dilihat dari hasil pekerjaan siswa yaitu ketika siswa tidak menuliskan pemisalan variabel dari soal cerita yang diberikan, siswa tidak membuat model matematika yang sesuai dengan kalimat cerita yang ada pada soal serta tidak menuliskan metode dan langkah-langkah 
yang akan mereka gunakan dalam menyelesaikan model matematika yang telah dibuatnya; c) Kesalahan melaksanakan rencana, dilihat dari hasil pekerjaan siswa yaitu ketika siswa tidak menyelesaikan model matematika yang telah dibuatnya sesuai dengan langkah-langkah penyelesaian yang telah disusunnya, siswa lupa atau salah menuliskan operasi dalam perhitungan, salah dalam menghitung, dan salah dalam menuliskan satuan serta tidak menuliskan kesimpulan sesuai dengan permasalahan yang diberikan; dan d) Kesalahan memeriksa kembali solusi yang diperoleh, dilihat dari hasil pekerjaan siswa yaitu ketika siswa menuliskan pembuktian tanpa melalui langkah-langkah yang seharusnya diselesaikan terlebih dahulu (sistematis). 2) Persentase dari masing-masing jenis kesalahan yang dilakukan siswa yaitu: a) Kesalahan memahami soal sebesar 4,4\%; b) Kesalahan menyusun rencana sebesar $16,5 \%$; c) Kesalahan melaksanakan rencana sebesar 17,0\%; dan d) Kesalahan memeriksa kembali solusi yang diperoleh sebesar $14,8 \%$

\section{DAFTAR PUSTAKA}

Abdurrahman, M. (2012). Anak Berkesulitan Belajar Teori, Diagnosis, Dan Remediasinya. Jakarta: Rineka.

Ali, M. (1993). Strategi penelitian Pendidikan. Bandung: Angkasa.

Diona Amelia, Susanto, A. F. (2015). Analisis Hasil Belajar Matematika Siswa Pada Pokok Bahasan Himpunan Berdasarkan Ranah Kognitif Taksonomi Bloom Kelas VII-A di SMPN 14 Jember Basic Cognitive Bloom Taxonomy Class VII-A in SMPN 14 Jember ). Jurnal Edukasi UNEJ, 2(1), 1-4.

Lestari, W. (2017). Pengaruh Kemampuan Awal Matematika dan Motivasi Belajar Terhadap Hasil Belajar Matematika. Jurnal Analisa, 3(1), 76-84.

Mulyati. (2016). Peningkatan Kemampuan Pemahaman dan Representasi Matematis Siswa SMA Melalui Strategi PreviewQuestion-Read-Replect-Recite-Review.
Jurnal Analisa, II(September), 36-55. Nugrahani, A. (2017). Analisis Kesalahan dalam Menyelesaikan Soal Cerita pada Materi Himpunan Berdasarkan Tahapan Newman pada Siswa Kelas VII A SMP Kristen Satya Wacana Salatiga. Universitas Kristen Satya Wacana. https://doi.org/10.1177/175791391456654 9.

Nurul Farida. (2015). Analisis Kesalahan Siswa SMP KELAS VIII dalam Menyelesaikan Masalah Soal Cerita Matematika. Aksioma Jurnal Pendidikan Matematika FKIP Univ. Muhammadiyah Metro, 4(2), 4252.

Rohimah, S., \& Maryono, I. (2017). Implementasi Advance Organizer Dan MApos Dalam Meningkatkan Kemampuan Pemahaman Matematis. Jurnal Analisa, 3(1), 93-105.

Susilawati, E., Syaf, A. H., \& Susilawati, W. (2017). Pendekatan Eksplorasi Berbasis Intuisi Pada Kemampuan Pemecahan Masalah Matematis. Pendidikan Matematika, 3(2), 138-147. 